\title{
Trichosporon asteroides: A novel etiologic agent of Kerion celsi in a child
}

\section{Trichosporon asteroides: Çocukta Kerion celsi için yeni bir etken}

\author{
Bilge ALDEMİR KOCABAŞ ${ }^{1}$, Adem KARBUZ ${ }^{1}$, Ergin ÇİFTÇi' ${ }^{1}$, Firat BEĞdE ${ }^{2}$, Selver AMETOGLOU ${ }^{2}$, \\ Ali Adil FOUAD ${ }^{3}$, Ayşe KALKANCI ${ }^{3}$, Zeynep Ceren KARAHAN ${ }^{4}$, Derya AYSEV ${ }^{2}$, Erdal İNCE ${ }^{1}$ \\ ${ }^{I}$ Ankara Üniversitesi Tıp Fakültesi, Cocuk Enfeksiyon Hastalıkları Bilim Dalı, Ankara \\ ${ }^{2}$ Ankara Üniversitesi Tıp Fakültesi, Çocuk Sağll $\breve{g l}$ ve Hastalıkları Anabilim Dalı, Ankara \\ ${ }^{3}$ Gazi Üniversitesi Tip Fakültesi, Tıbbi Mikrobiyoloji Bilim Dalı, Ankara \\ ${ }^{4}$ Ankara Üniversitesi Tıp Fakültesi, Tıbbi Mikrobiyoloji Bilim Dalı, Ankara
}

\begin{abstract}
Kerion celsi is generally known as an inflammatory form of tinea capitis which is the result of delayed type hypersensitivity reaction of the body to fungal agents. It causes a painful, inflamed, crusty mass on the scalp and is often associated with purulent drainage and regional lymphadenopathy. Kerion celsi is often reported in children between three to seven years of age and it has a male predominance. This diagnosis should be kept in mind in patients with scalp scaling and alopecia, especially if they have pustular, crusted and nodular lesions and easily breaking hairs on the scalp. If untreated, alopecic scar tissue inevitably develops on the scalp. Differential diagnosis with bacterial pyoderma or abscess is important and may avoid unnecessary and inappropriate surgical drainage. Although causative species show variations between regions, zoophilic dermatophytes such as Microsporum canis, Trichophyton verrucosum and Trichophyton interdigitale complex are usually isolated from cultures. Herein, we report a ten year-old boy who was referred to our clinic because of pyodermic skin lesion and abscess formation which did not respond to antibacterial treatment. He was diagnosed as kerion celsi related to Trichosporon asteroides and successfully treated with systemic fluconazole within eight weeks. To our knowledge this is the first case of kerion celsi in the literature caused by $T$. asteroides.
\end{abstract}

Key words: Kerion celsi, tinea capitis, trichosporon asteroides

0̈Z

Kerion celsi, genellikle inflamatuvar tipte tinea capitis olarak bilinen ve vücudun fungal etkenlere karşı geliştirdiği geç tip bir hipersensitivite reaksiyonudur. Saçlı deride ağrı ve enflamasyonun eşlik ettiği krutlu bir tabaka gelişimine neden olur ve sıklıkla akıntı ve bölgesel lenfadenopati ile birliktedir. Hastalık 3-7 yaş arasında ve erkek çocuklarda daha sık olarak bildirilmektedir. Saçlı deride saç kaybı, püstüler ve nodüler lezyon üzerinde akıntılı ve kurutlu bir tabaka gelişmesi, lezyon üzerine basıldığında pü gelmesi ve saçların kolaylıkla çekilince kayarak kopması durumunda akla gelmelidir. Tedavi edilmediği takdirde saçlı deride alopesik skar dokusu gelişimi kaçınılmazdır. Gereksiz ve uygun olmayan cerrahi drenaj işleminin önlenebilmesi için bakteriyel piyodermi ve abseler ile ayırıcı tanısı önem taşımaktadır. Etiyolojik ajanlar bölgelere göre farklılık göstermekle birlikte Microsporum canis, Trichophyton verrucosum and Trichophyton interdigitale kompleks gibi zoofilik dermatofitler sıklıkla izole edilir. Burada, kliniğimize antibiyotik tedavisine yanıtsız bakteriyel piyodermi ve abse ön tanısı ile yönlendirilen ve Trichosporon asteroides'e bağlı kerion celsi tanısı konularak 8 haftalık flukanozol ile başarılı şekilde tedavi edilen 10 yaşında bir erkek çocuk olgu sunulmaktadır. Hastamızı T. asteroides'in etken olduğu ilk kerion celsi olgusu olarak sunmaktayı.

Anahtar kelimeler: Kerion celsi, tinea capitis, trichosporon asteroides

Alındığı tarih: 04.03 .2016

Kabul tarihi: 29.03.2016

Yazışma adresi: Uzm. Dr. Bilge Aldemir Kocabaş, Ankara Üniversitesi Tıp Fakültesi, Çocuk Enfeksiyon Hastalıkları Bilim Dalı, Ankara e-mail: drbaldemir@gmail.com 


\section{INTRODUCTION}

Tinea capitis is a fungal infection of the scalp caused by dermatophytes. It can be seen in three different clinical forms such as "tinea capitis superficialis, tinea capitis profunda [Kerion celsi $(\mathrm{KC})]$ and favus" according to the severity of inflammation. KC is also known as the inflammatory type of tinea capitis which is a hypersensitivity reaction of the body to fungal agents ${ }^{(1-4)}$. $\mathrm{KC}$ is often reported in prepubertal boys. Hair loss on the scalp, development of pustules, nodules and scar formation on the scalp and also the id reaction, erythema nodosum, have been reported in untreated patients ${ }^{(1-4)}$. The differential diagnosis from the bacterial pyoderma and abscess is very important because generally antifungal therapy is effective in the treatment. Causative species show variations among regions, the most reported agents are zoophilic dermatophytes ${ }^{(5,6)}$. Although Trichosporon species are the causative agents of cutaneous infections, there is no $\mathrm{KC}$ case associated with $T$. asteroides in the literature. To our knowledge, this is the first case caused by T. asteroides up to now.

\section{CASE PRESENTATION}

A previously healthy 10 -year-old boy was admitted to our hospital with complaints of swelling, discharge and pain behind his right ear. His medical history revealed a painless small lesion detected behind his right ear twenty days ago which had expanded within 3-4 days. A treatment regimen including topical mupirocin ointment and oral amoxacillin-clavulanic acid was started at an outpatient clinic with a diagnosis of pyoderma. Then, terbinafine therapy was administered in another center with the diagnosis of favus due to increasing lesion size. There was no trauma history and initial physical examination in our clinic revealed a painful and yellow colored purulent discharge and hair loss at an about $3 \times 2 \mathrm{~cm}$ area on the scalp behind the right ear. There also was a mobile, painful palpable lymphadenopathy in the postauricular region (Fig. 1). His axillary body temperature was $36.0^{\circ} \mathrm{C}$. His laboratory findings were as follows; hemoglobin level: $14 \mathrm{~g} / \mathrm{dL}$, white blood cell count: $8.400 / \mathrm{mm}^{3}$, platelet count: $278.000 / \mathrm{mm}^{3}$, erythrocyte sedimentation rate: 14 $\mathrm{mm} / \mathrm{h}$, and C-reactive protein level: $5.4 \mathrm{mg} / \mathrm{L}$. The skin lesion was consistent with $\mathrm{KC}$ and the swab culture from patient's lesion was sent to the laboratory for bacterial and fungal cultivation. Intravenous fluconazole $(10 \mathrm{mg} / \mathrm{kg} /$ day $)$ was initiated taking into account his previous history of terbinafine treatment. Also, ketoconazole shampoo was prescribed for two days a week. Contact isolation precautions were applied and the family was informed. Neither systemic nor topical antibacterial therapy was prescribed. The reduction of pain and erythema was observed on the lesion within the first three days of treatment. Discharge was significantly reduced at the end of the first week and incrustation was observed on the lesion surface. He did not have febrile episodes during the follow-up.

Trichosporon colonies were detected on Sabouraud Dextrose Agar (SDA) plates. Rapid growing yeastlike colonies results in appearance of wrinkled, glabrous and waxy, white to cream colored skin lesions. The wrinkled appearance became more prominent in time. Heaping at the center of the colony is typical.

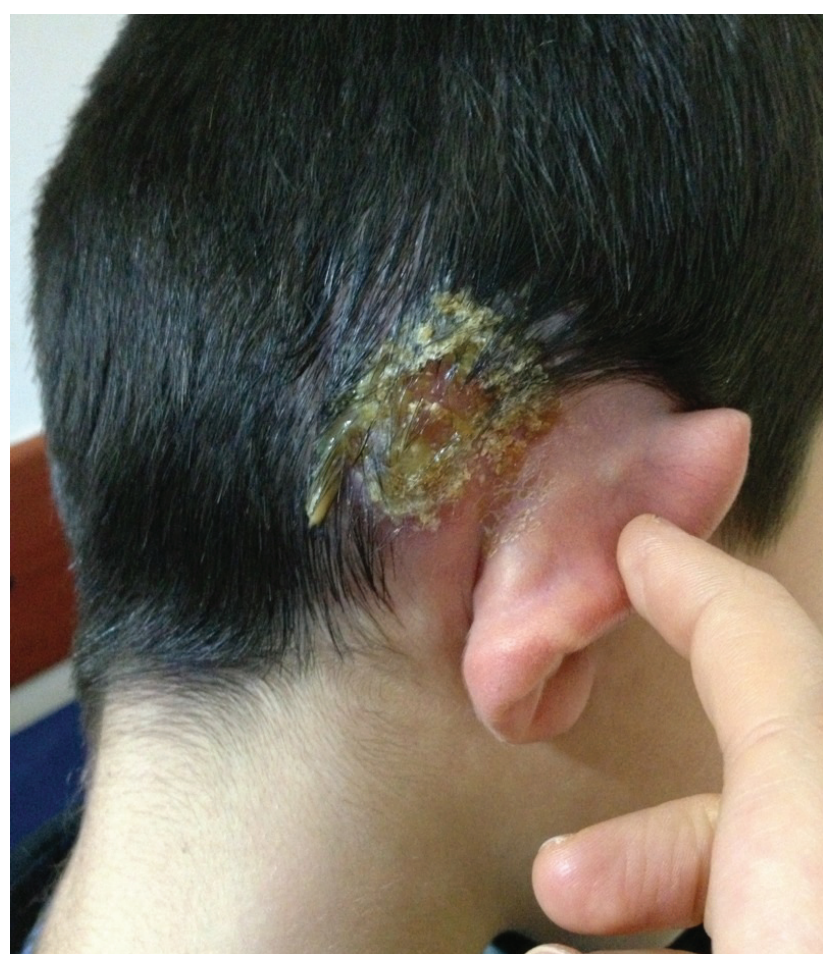

Figure 1. Photo image shows kerion celsi lesion of the patient causing yellow colored purulent discharge, hair loss at the scalp behind of the right ear and a painful palpable lymphadenopathy in the postauricular region. 
Urease enzyme production was a significant feature of this genus. After $72 \mathrm{~h}$ of incubation at $25^{\circ} \mathrm{C}$ on cornmeal Tween 80 agar Trichosporon produced abundant and well-developed pseudohyphae and hyphae. Blastoconidia were unicellular and variable in shape. The most typical microscopic feature of this genus is production of arthroconidia. These arthroconidia are unicellular and usually cubical, barrel- shaped or elongated. However identification of the isolate could not be made based on microbiological appearance. DNA sequencing was additionally performed for the molecularidentification of Trichosporon isolate. The ITS1 region of 5.8S rRNA gene was sequenced directly from PCR products using the primer pairs (5'-GTC GTA ACA AGG TTA ACC TGC GG-3'; 5'-TCC TCC GGT TAT TGA TAT GC-3'). The PCR products were sequenced using an ABI 310 DNA sequencer and a BigDye Terminator Cycle Sequencing Ready Reaction kit (Perkin-Elmer) according to the manufacturer's instructions. The sequence data were analyzed using the National Center for Biotechnology Information (Bethesda, Md., USA) BLAST system (available at http://www.ncbi.nlm.nih.gov/BLAST/). The sequence of our case, isolate was $99 \%$ identical to that of AB018017, AF075513 thus, molecular product was identified as Trichosporon asteroides.

The patient was discharged on the 8th day of intravenous treatment with the prescription of oral fluconazole (4 mg/kg/day) and called for a control visit after four weeks. The lesion was found to be significantly resolved at the control visit. Two days weekly oral fluconazole therapy was continued for four more weeks and the therapy regimen was completed within eight weeks. At the end of the 8th week, new hair formation was observed on the lesion (Fig. 2) and the treatment was stopped.

\section{DISCUSSION}

Tinea capitis is a scalp infection caused by dermatophytes. $\mathrm{KC}$ is an inflammatory form of tinea capitis. It occurs as a reaction of the body against fungal elements mediated by cellular immunity. Development of pustules and nodules on the scalp, scalp scaling, alopecia, and easily breaking hairs on the scalp are

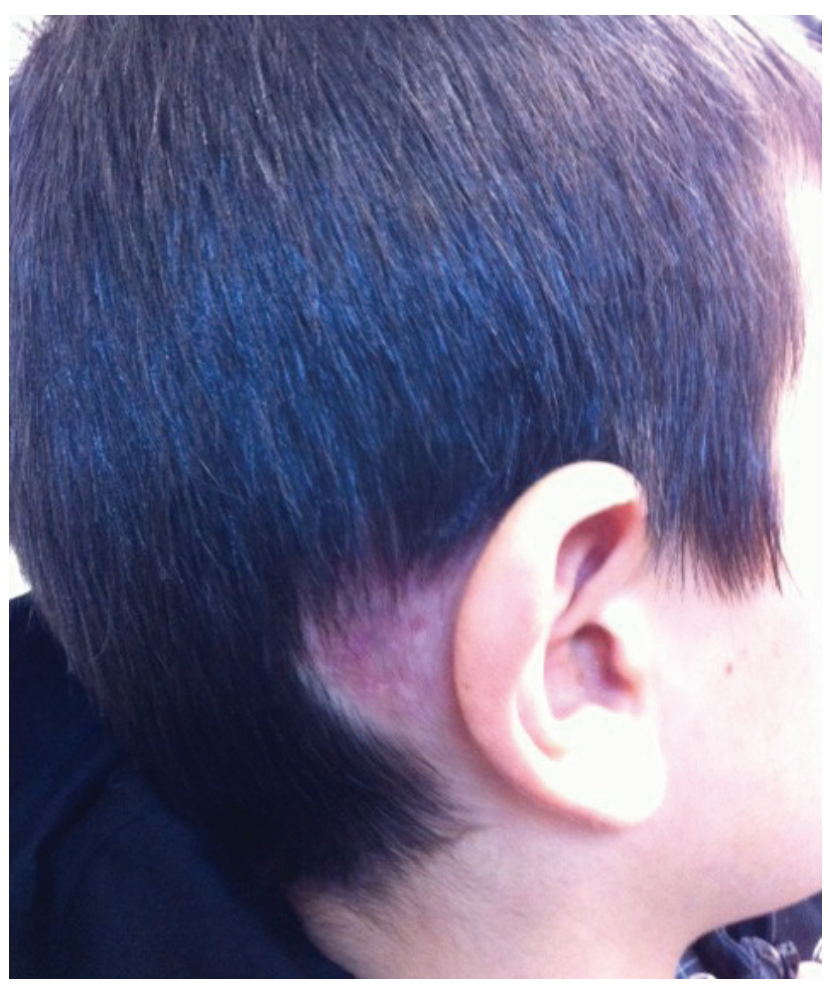

Figure 2. Photo image of the patient after eight weeks of fluconazole treatment. Crusted, pustular lesions and lymphadenopathy disappeared and new hair formation of is remarkable.

typical findings. Pyoderma and abscess formation can complicate the differential diagnosis due to pus, pain and tenderness on the surface of the lesion with secondary reactive lymphadenopathy. The development of alopecic scar tissue is inevitable in untreated patients ${ }^{(1-4)}$. Although zoophilic dermatophytes (M. canis, T. verrucosum and T. interdigitale complex) are more common etiological agents, anthropophilic (T. rubrum), and geophilic (M. gypseum) dermatophyte species can also result in the disease. The causative species may vary among regions ${ }^{(5,6)}$. In a study published in 2009, Microsporum canis was reported as the most common cause of $\mathrm{KC}$ between 1981 and 1985, and Trichophyton tonsurans between 2000-2008 (2). In another study, the most common species detected was Trichophyton violaceum ${ }^{(5)}$.

Trichosporon species may colonize different parts of the body such as oral cavity, gastrointestinal system, urinary tract or the skin ${ }^{(7)}$. Although molecular methods are required for accurate identification of this genus, they are still not cost- effective and not suitable for routine evaluation ${ }^{(8)}$. Trichosporon aste- 
roides is associated with superficial cutaneous infections. It also has been reported as an agent capable of causing systemic infections ${ }^{(7-9)}$. Up to date, this agent has not been reported as the etiological factor for $\mathrm{KC}$ in the literature. In this case report, we present the first case of $\mathrm{KC}$ due to T. asteroides.

$\mathrm{KC}$ is a rare form of dermatophytosis and its frequency differs from $1.5 \%$ to $19.8 \% 5$. It is often seen in boys between 3-7 years of age and rarely detected after puberty due to hormonal changes and fungistatic free fatty acids of the sebum ${ }^{(5,6)}$. Living in rural areas, poor hygiene, crowded environments and low socio-economic conditions are associated with high prevalence. Poor immune response and epidermal immaturity in infants, humid environment, use of broad-spectrum antibiotics are other risk factors of $\mathrm{KC}^{(5,6,10,11)}$. Contact with infected children and animals, diabetes mellitus, anemia, immune suppression and the use of topical and systemic steroids are responsible factors for adult- onset disease ${ }^{(5,11,12)}$.

Griseofulvin (20 mg/kg/day for a period of 6-12 weeks) is the recommended treatment regimen in children ${ }^{(13,14)}$. In recent years, new antifungal agents (fluconazole, terbinafine, itraconazole) have been increasingly used for treatment (14-16). Fluconazole may be a safe and effective choice in childhood ${ }^{(16)}$. Although corticosteroids can prevent scar formation in KC patients, these agents should be chosen carefully in terms of side effects in children ${ }^{(5)}$. If differential diagnosis of $\mathrm{KC}$ is considered, incision and drainage should be avoided. Use of topical selenium sulfide, zinc pyrithione, povidone iodide or ketoconazole shampoo was shown to be effective in the prevention of spreading the spores to the environment. Application of shampoo for five minutes with a dosing schedule of two times a week for a period of 2-4 weeks is recommended. Contact isolation precautions should be taken and personal hygienic equipment should be disinfected. Some experts suggest going to school and daycare center immediately after starting oral and topical treatment ${ }^{(6)}$.

In conclusion, this is the first case report of $\mathrm{KC}$ due to $T$. asteroides which has not been reported in the literature so far . We also emphasized that differential diagnosis formbacterial pyoderma or abscess is important and clinicians should avoid unnecessary and inappropriate surgical drainage.

Conflicts of interest: No conflicts of interest. Financial support: None.

\section{REFERENCES}

1. Yılmaz S, Gümüş N, Erin ÖF, Çelik UR, Erçöçen AR. Travmatik saçlı deri yarası ile kerion celsi birlikteliğii: nadir bir hasta. Turk Plast Surg 2011;19:138-140.

2. Iwasawa M, Yorifuji K, Sano A, Takahashi Y, Nishimura K. Case of kerion celsi caused by Microsporum gypseum (Arthroderma gypseum) in a child. Nihon Ishinkin Gakkai Zasshi 2009;50:155-160. http://dx.doi.org/10.3314/jjmm.50.155

3. Rojat P, Hennequin C, Zaharia D, et al. Accidental Trichophyton mentagrophytes fungemia during the course of kerion celsi. Mycoses 2012;55:29-31.

4. Zaraa I, Trojjet S, El Guellali N, et al. Childhood erythema nodosum associated with kerion celsi: a case report and review of literature. Pediatr Dermatol 2012;29:479-482. http://dx.doi.org/10.1111/j.1525-1470.2011.01523.x

5. Zaraa I, Hawilo A, Aounallah A, et al. Inflammatory Tinea capitis: a 12-year study and a review of the literature. Mycoses 2013;56:110-116. http://dx.doi.org/10.1111/j.1439-0507.2012.02219.x

6. Thakur R. Tinea capitis in Botswana. Clin Cosmet Investig Dermatol 2013;6:37-41. http://dx.doi.org/10.2147/CCID.S40053

7. Kustimur S, Kalkanci A, Caglar K et al. Nosocomial fungemia due to Trichosporon asteroides: firstly described bloodstream infection. Diagn Microbiol Infect Dis 2002;43:167-170. http://dx.doi.org/10.1016/S0732-8893(02)00385-1

8. Chagas-Neto TC, Chaves GM, Melo AS et al. Bloodstream infections due to Trichosporon spp: species distribution, Trichosporon asahii genotypes determined on the basis of ribosomal DNA intergenic spacer 1 sequencing, and antifungal susceptibility testing. J Clin Microbiol 2009;47:1074-1081. http://dx.doi.org/10.1128/JCM.01614-08

9. Kalkanci A, Sugita T, Arikan S et al. Molecular identification, genotyping, and drug susceptibility of the basidiomycetous yeast pathogen Trichosporon isolated from Turkish patients. Med Mycol 2010;48:141-146.

http://dx.doi.org/10.3109/13693780902977984

10. Larralde M, Gomar B, Boggio P, Abad ME, Pagotto B. Neonatal kerion Celsi: report of three cases. Pediatr Dermatol 2010;27:361-363. http://dx.doi.org/10.1111/j.1525-1470.2010.01169.x

11. Romano C, Gianni C, Papini M. Tinea capitis in infants less than 1 year of age. Pediatr Dermatol 2001;18:465-468. http://dx.doi.org/10.1046/j.1525-1470.2001.1861997.x

12. Terragni L, Lasagni A, Oriani A. Tinea capitis in adults. Mycoses 1989;32:482-486.

http://dx.doi.org/10.1111/j.1439-0507.1989.tb02287.x

13. Lateur N, André J, De Maubeuge J, Poncin M, Song M. Tinea capitis in two black african adults with HIV infection. $\mathrm{Br} J$ Dermatol 1999;140:722-724. http://dx.doi.org/10.1046/j.1365-2133.1999.02778.x

14. Proudfoot LE, Higgins EM, Morris-Jones R. A retrospective study of the management of pediatric kerion in Trichophyton tonsurans infection. Pediatr Dermatol 2011;28:655-657. http://dx.doi.org/10.1111/j.1525-1470.2011.01645.x

15. Liu ZH, Shen H, Xu AE. Severe kerion with dermatophytid reaction presenting with diffuse erythema and pustules. Mycoses 2011;54:650-652. http://dx.doi.org/10.1111/j.1439-0507.2010.01973.x

16. González U, Seaton T, Bergus G, Jacobson J, Martínez-Monzón C. Systemic antifungal therapy for tinea capitis in children. Cochrane Database Syst Rev 2007;17:4. http://dx.doi.org/10.1002/14651858.cd004685.pub2 